\title{
Four Decades Research on Higher Vocational Education: A Bibliometric Review
}

\author{
1Khairul Hafezad Abdullah \\ Email : khairul085@uitm.edu.my* \\ * : coresponndensing author \\ ${ }^{1}$ SAS Young Research Fellow Member, Scholars Academic and Scientific Society, 204 Borhawor, Murajhar \\ Hojai, Assam, India;
}

Article history

Received June 25, 2021

Revised Sep 16, 2021

Accepted Nov 30, 2021

Keywords

Higher Vocational Education

Educational System

Bibliometrics

Publication Trends

Scopus
Vocational education is seen as an integral part of the educational system, either at the school level or at a post-secondary level. It is indicated that vocational education has immensely influenced life and plays a vital role in evolving societies worldwide. Thus, analysing this scientific domain's evolution and creation is essential. This study discusses the bibliometric review of scholarly research performed in higher vocational education in recent years. The Scopus database and a wide range of bibliometric metrics, including descriptive and trend analysis of publications related to higher vocational education, were examined in greater depth. A graphical visualisation of bibliographic details using the VOS viewer software is also presented. Results show that the number of studies covering this subject has fluctuated, with the highest number of publications is 65 in 2020. Often, by reviewing publications and research areas, it can be construed that higher vocational education research is diverse, including social sciences, computer science, and engineering. The bibliometric review conducted offers a rigorous and thorough view of higher vocational education research that may benefit higher vocational education practitioners and researchers keen on the pursuit of enhancing or discovering new knowledge in this field.

This is an open access article under the CC-BY-SA license.

\section{Introduction}

Principally, education is an essential facet that allows people to acquire competence, take up social responsibilities, increase the quality of life, develop proper skills, generate income, and become more competitive in the labour market. Besides, education accords people to reach the full potential of their multiple abilities, together with cognitive, emotional, and creativity (Llamazares de Prado, Arias Gago, \& Melcon Alvarez, 2021). In vocational education, the curriculum that has been set up should be based on the need for vocational skills, where the person's abilities are accredited, and the individual's successes are recognised (Kamasheva et al., 2016). The reason is that individuals with vocational skills are easy to be attracted to the labour market due to the knowledge attained during vocational training (Koudahl, 2010). Furthermore, due to the growing 
economy and an increasing skilled worker shortage, vocational education has come into focus and attention was paid to the skill development agenda for more than a decade (Pilz \& Regel, 2021).

Vocational education is viewed as obligatory for a country's educational system, either at the school or higher institutions (Siddiky \& Uh, 2020). The following few years' priority directions are to support the vocational education system; thus, vocational education is a tool to develop a social and economic plan that requires support from secondary, higher education and postgraduate institutions (Kamasheva et al., 2016). Also, the existence of career competencies among students in higher vocational educational institutions correlates with a learning environment characterised by a practice-based and inquiry-based curriculum, which provides students with the opportunity to explore possible career paths (Kuijpers \& Meijers, 2012). It is also worth noting that, in the era of the knowledge economy, higher institutions, including colleges and universities, must develop and innovate interdisciplinary talents and update the vocational educational impression to cultivate the skills of students (Handayani, Ali, \& Mukhidin, 2020; Sun, Cui, \& Xu, 2018).

Today, society needs more employable workers who can master technology and have more sophisticated and cross-disciplinary skills (McGunagle \& Zizka, 2020). Therefore, higher education's future growth is a centrepiece for progress and reform of the development model and the convergence of technological and humanistic education (Sun et al., 2018). Additionally, in response to global competition, higher education has evolved to consider new challenges and paradigms and has focused on training graduates with diverse skills and competencies for the future economy (Smirnova et al., 2019). Consequently, there is a need to teach by a practiceoriented approach to make sure students learn the needed theoretical knowledge and are ready for specific actions. The importance of vocational education for countries includes its practical applications and socioeconomic and environmental benefits (Chukwu et al., 2020; Özer \& Suna, 2019).

Besides the fact that higher vocational education is necessary for countries from various perspectives, there are many different views on how higher vocational education should be restructured in the $21^{\text {st }}$ century. Bakhtiyorovna (2020) claims that the current structure of higher pedagogical education is focused on applying the competency-based approach that helps improve vocational educational standards. This is because the complex technological advances of the information and technology industry have caused changes in the labour market and consumer behaviour (Özer \& Suna, 2019). Also, vocational education policies are continually enforced and changed to ensure that society can meet industrial revolution 4.0. (Yaakob et al., 2020). As things go, labour market demand for high-skilled workers is increasing due to the expansion of knowledge-based occupations and industries (Webb et al., 2017), and within the context of 
digitalisation, a significant challenge that vocational education programmes face is the rapidity and unpredictability of technology and economic change (Wild \& Heuling, 2020).

In recent years, there have been publications in educational research to analyse the number of studies on a specific theme or element. Bibliometric studies have also been performed in the fields of education, for example, entrepreneurship (Aparicio, Iturralde, \& Maseda, 2019), mathematics (Özkaya, 2018), engineering (Xian \& Madhavan, 2014), and medicine (Azer, 2015). In summary, a limited bibliometric research review on publication patterns in higher vocational education has been performed. Thus, thorough and up-to-date bibliometric research on higher vocational education is urgently required.

This study has been designed to learn from the bibliometric review of higher vocational education from the angle of (i) global trend of publications, (ii) most influential countries, (iii) most influential journals, (iv) most productive and influential authors, (v) most productive and influential institutions, (vi) analysis of research areas and (vii) network visualisation map of authors' keywords. The information provided in this study is projected to deliver a clear overview of a higher vocational education research direction that could enable readers and researchers to gain the knowledge that benefits their studies. The approach to this bibliometric review could create significant contributions to existing higher vocational education research.

\section{Method}

The phrase bibliometric derives from the terms biblio, which refers to books or other publications, and metrics, which denotes measurement (Broadus, 1987). Bibliometric is, therefore, best to elucidate as studying or quantifying books or other publications through various metadata that were available in multiple databases. Numerous databases are currently available for bibliometric analysis, including Google Scholar, Dimensions, Microsoft Academic, Scopus, PubMed, and Web of Science. Nonetheless, Scopus and Web of Science are the most frequented databases by prior researchers worldwide.

In this study, a bibliometric review is directed through the analysis of higher vocational education publications in the Scopus database. The investigation was completed within the descriptive analysis context using the document examination approach. In this review, the Scopus database was searched for "higher vocational education" keywords to retrieve the data on February 18, 2021. The Scopus database was selected because it has extensive documents compared to the Web of Science and Pubmed and has frequently been cited in previous studies (Sweileh, 2020). A total of 484 higher vocational education publications were found from 1980 to 2020 . Out of the 484 publications, there were 205 articles from various journal sources, 175 conference papers, 98 book series, and less than ten books. There are 452 publications written in English, 17 in Russian, 11 in 
Chinese, and less than five in other languages such as Slovenian, Spanish, and Dutch.

A bibliometric review was initialised by exported the list of publications in the form of Commaseparated Values (CSV) and Research Information Systems (RIS) format to Microsoft Excel, Publish or Perish (PoP), and VOSviewer software. The retrieved data compiled information related to the author's name, document source, year of publication, publication title, countries, journals, subject area, and type of articles. Using the VOSviewer program developed by Van Eck and Waltman (2010), the bibliometric review and mapping of higher vocational education publications were made conceivable. According to Van Eck and Waltman (2010; 2019), VOSviewer applied visual elements based on mapping techniques, converting data related to CSV format into diagrams or clusters. Also, mapping techniques help the researcher analyse specific information such as authors, locations, institutions, citations, co-citations, and other refining aspects (Khalil \& Crawford, 2015).

\section{Result and Discussion}

\section{Global Trend of Publications}

Figure 1 depicts how the publication of higher vocational education has been distributed from 1980 to 2020. It can be observed that the publication of higher vocational education began to increase by more than 20 in 2010. More precisely, the development of higher vocational education publications attracts researchers' interest after three decades, with 91.53 per cent of the total publications. The publications rose to 61 in 2011 and declined to 35 in 2012. However, in 2013, the number of publications had increased slightly with 39 publications and dropped to 24 publications in 2014. The number of publications experiences fluctuation until 2020. The increased number of higher vocational education publications in 2016 reflects the expansion of higher vocational education institutions and programmes, which feature many research outcomes in the forms of scholarly books, journal articles, and students' theses (Zha, Guangfen, \& Shiming, 2017). The highest number of higher vocational education was in 2020, with 65 publications.

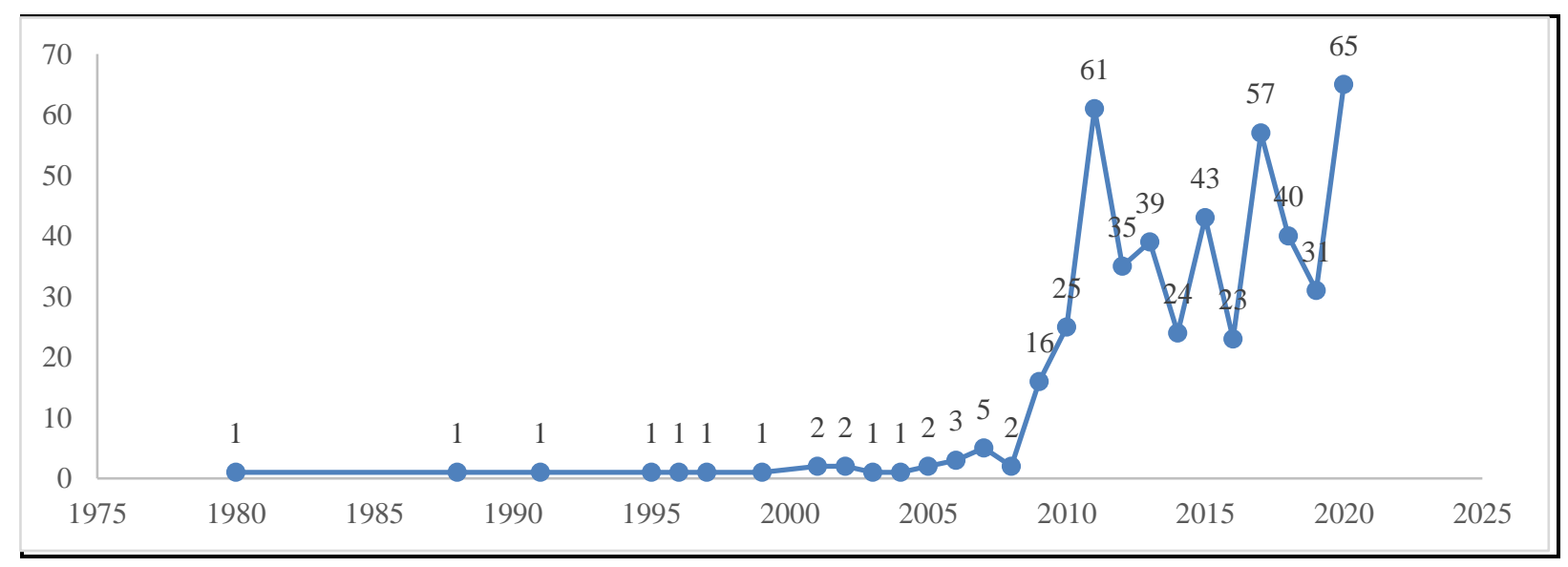

Fig 1: Global trends of publications in higher vocational education 
The higher number of publications indicated the rising keenness in higher vocational education research worldwide. This is because new forms of lifelong and higher vocational education are emerging in countries around the globe, and diversity in the formation and provision of higher education is growing (Köpsén, 2020). Also, vocational education is reviewed from an employment perspective. Despite high graduation rates, they are employed mainly outside of their field of education. Therefore, horizontal skill mismatch is widespread and attracts research interest (Özer \& Suna, 2019). The total of researchers globally and the increased number of higher vocational education publications in the Scopus database have undoubtedly affected the quantity and quality of publications. The expanding increase witnessed in higher vocational education journals is a reflection that can be construed that this research area is pertinent and reputable within academia.

\section{Most Influential Countries}

Analysis of the countries relative to the authors who have contributed to higher vocational education was executed through a network diagram. As revealed in Figure 2, the citations network analysis in this study consists of six countries that were divided into two clusters (green and red colours). The nodes designate the countries to signify the number of publications. The larger the nodes represented, the highest number of documents that a specific country has published. In this scenario, among the others, China provided more significant nodes with 311 documents. The second rank goes to the Russian federation with 48 documents, and the third position was the Netherlands with 35 documents. Those countries have ascertained to play an essential role in developing scientific contact in higher vocational education and act as a gateway to information. In this analysis, China became the most prominent country in publishing higher vocational education research because China's government focused on skills and skilled workers to cultivate its economy (Xiong, 2011). Besides, since the 21st century, China's higher vocational education has achieved remarkable achievements and played a fundamental and decisive role (Gao \& Yu, 2020).

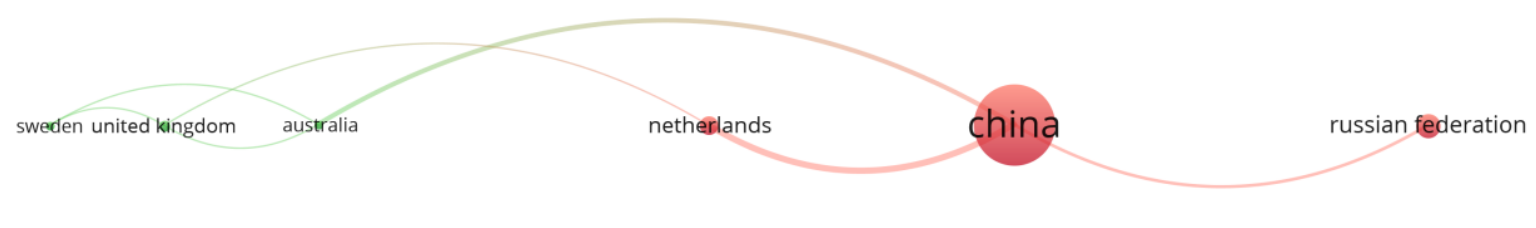

\section{VoSviewer}

Fig 2: Most influential countries in publishing higher vocational education 


\section{Most Influential Sources}

Table 1 reflects information on the most influential sources concerning higher vocational education publications, ranked based on their number of publications. A list of 13 journals with at least seven publications is presented. It is found that the Journal of Physics Conference Series grows into the most influential sources with a total of 28 publications over four decades. Ranked second in this analysis is the Lecture Notes in Electrical Engineering, and the Advances in Intelligent and Soft Computing is positioned at the third rank.

Based on this finding, it is suggested that these top three sources have contributed valuable knowledge that will allow prospective researchers to source them and be beneficial for their future higher vocational education studies. The information provided also conveys a message that the Journal of Physics Conference Series, making it easy for readers to identify and exploit relevant details. According to Eduard and Shashkin (2019), researchers from the Top 100 leading universities and dozens of scientific organisations participate annually in the conference conducted by the Journal of Physics Conference Series, which shows that these sources have attracted researchers worldwide.

Table 1. Most influential sources in publishing higher vocational education

\begin{tabular}{lc}
\hline \multicolumn{1}{c}{ Sources } & Publications \\
\hline Journal of Physics Conference Series & 28 \\
Lecture Notes in Electrical Engineering & 24 \\
Advances in Intelligent and Soft Computing & 21 \\
Agro Food Industry Hi Tech & 19 \\
Advanced Materials Research & 12 \\
Journal of Advanced Oxidation Technologies & 11 \\
Applied Mechanics and Materials & 10 \\
Chinese Education and Society & 10 \\
Advances in Intelligent Systems and Computing & 9 \\
Journal of Vocational Education and Training & 8 \\
Lecture Notes of The Institute for Computer Sciences Social Informatics and & \\
Telecommunications Engineering & 8 \\
ACM International Conference Proceeding Series & 7 \\
Communications in Computer and Information Science & 7 \\
\hline
\end{tabular}

\section{Most Productive and Influential Authors}

The next step was to recognise the most active and successful writers in the publication of higher vocational education. A list of the ten most-cited documents is provided in Table 2. Although several factors can affect a paper's vital significance, the number of citations is generally seen as a 
fair representation of their work's influence and how they are favoured among the scientific community (Abdullah \& Abd Aziz, 2020).

As indicated in Table 2, the most cited work was taken up by Billet for the 2009 article, entitled "Realising the educational worth of integrating work experiences in higher education", obtained 183 citations. And, ranked after it was Albersnagel's work which has been published in 1988, received 96 citations for an article entitled "Velten and musical mood induction procedures: A comparison with the accessibility of thought associations". These two publications' insights helped identify the most prominent higher vocational education researchers to be considered in future studies.

Table 2. Most influential authors in publishing higher vocational education

\begin{tabular}{|c|c|c|c|c|}
\hline Cites & Cites Per Year & Authors & Title & Year \\
\hline 183 & 15.25 & S. Billett & $\begin{array}{l}\text { Realising the educational worth of } \\
\text { integrating work experiences in } \\
\text { higher education }\end{array}$ & 2009 \\
\hline 96 & 2.91 & F.A. Albersnagel & $\begin{array}{l}\text { Velten and musical mood induction } \\
\text { procedures: A comparison with } \\
\text { accessibility of thought associations }\end{array}$ & 1988 \\
\hline 66 & 5.5 & $\begin{array}{l}\text { H. Biemans, R. Wesselink, J. } \\
\text { Gulikers, S. Schaafsma, J. } \\
\text { Verstegen, M. Mulder }\end{array}$ & $\begin{array}{l}\text { Towards competence-based VET: } \\
\text { Dealing with the pitfalls }\end{array}$ & 2009 \\
\hline 58 & 2.23 & J.C. van Ours, G. Ridder & $\begin{array}{c}\text { Job matching and job competition: } \\
\text { Are lower educated workers at the } \\
\text { back of job queues? }\end{array}$ & 1995 \\
\hline 50 & 4.17 & $\begin{array}{l}\text { M.M. Hensen, M.R. De Vries, } \\
\text { F. Cörvers }\end{array}$ & $\begin{array}{l}\text { The role of geographic mobility in } \\
\text { reducing education-job mismatches } \\
\text { in the Netherlands }\end{array}$ & 2009 \\
\hline 42 & $\begin{array}{l}\mathrm{V} \\
\mathrm{A}\end{array}$ & $\begin{array}{l}\text { G.C.W. Wendel-Vos, A.E. } \\
\text { Dutman, W.M.M. } \\
\text { Verschuren, E.T. Ronckers, } \\
\text { A. Ament, P. van Assema, J. } \\
\text { van Ree, E.C. Ruland, A.J. } \\
\text { Schuit }\end{array}$ & $\begin{array}{l}\text { Lifestyle Factors of a Five-Year } \\
\text { Community-Intervention Program. } \\
\text { The Hartslag Limburg Intervention }\end{array}$ & 2009 \\
\hline 36 & 4 & M. Kuijpers, F. Meijers & $\begin{array}{l}\text { Learning for now or later? Career } \\
\text { competencies among students in } \\
\text { higher vocational education in the } \\
\text { Netherlands }\end{array}$ & 2012 \\
\hline 33 & 3.3 & L. Baartman, L. Ruijs & $\begin{array}{l}\text { Comparing students perceived and } \\
\text { actual competence in higher } \\
\text { vocational education }\end{array}$ & 2011 \\
\hline 33 & 3 & T.-Y. Chang, J.-M. Hsu & $\begin{array}{c}\text { Development framework for tourism } \\
\text { and hospitality in higher vocational } \\
\text { education in Taiwan }\end{array}$ & 2010 \\
\hline 25 & 1.32 & $\begin{array}{l}\text { A.W.M. Hoogveld, F. Paas, } \\
\text { W.M.G. Jochems, J.J.G. Van } \\
\text { Merriënboer }\end{array}$ & $\begin{array}{l}\text { Exploring teachers' instructional } \\
\text { design practices from a systems } \\
\text { design perspective }\end{array}$ & 2002 \\
\hline
\end{tabular}

Additional critical use of bibliometric analyses is to determine the most influential authors in higher vocational education. Table 3 reflects seven authors with at least three publications related 
to higher vocational education. Gong, S. affiliated with the Zhejiang Business Technology Institute, Ningbo, China, became the top list with five vocational education research articles. Next in line was Biemans, H. affiliated to Wageningen University \& Research, Wageningen, the Netherlands, with three publications. Biemans, H. was shared position with other five authors, namely, Gulikers, J. (Wageningen University \& Research, Wageningen, the Netherlands), Ma, L. (China University of Mining and Technology, Xuzhou, China), Tang, H. M. (Shanghai University of Medicine \& Health Sciences, Shanghai, China), Wang, F. M. (Shanghai University of Medicine \& Health Sciences, Shanghai, China), and Xiong, J. (Government of Alberta, Edmonton, Canada).

Table 3. Seven most productive authors in publishing higher vocational education

\begin{tabular}{|c|c|c|c|c|}
\hline Author & Publication & H-index & Current Affiliation & Country \\
\hline Gong, S. & 5 & 13 & Zhejiang Business Technology Institute, Ningbo & China \\
\hline Biemans, $\mathrm{H}$. & 3 & 27 & $\begin{array}{c}\text { Wageningen University \& Research, } \\
\text { Wageningen }\end{array}$ & Netherlands \\
\hline Gulikers, J. & 3 & 15 & $\begin{array}{c}\text { Wageningen University \& Research, } \\
\text { Wageningen }\end{array}$ & Netherlands \\
\hline Ma, L. & 3 & 5 & $\begin{array}{c}\text { China University of Mining and Technology, } \\
\text { Xuzhou }\end{array}$ & China \\
\hline Tang, H.M. & 3 & 3 & $\begin{array}{c}\text { Shanghai University of Medicine \& Health } \\
\text { Sciences, Shanghai }\end{array}$ & China \\
\hline Wang, F.M. & 3 & 1 & $\begin{array}{c}\text { Shanghai University of Medicine \& Health } \\
\text { Sciences, Shanghai }\end{array}$ & China \\
\hline Xiong, J. & 3 & 1 & Government of Alberta, Edmonton & Canada \\
\hline
\end{tabular}

It is noteworthy that over the last 40 years, authors who originated in China have been the most active in higher vocation education research. The results also supported previous findings related to China's most influential countries (see subtopic 3.2). The reason strongly supports the fact that China's government is transparent about the need for investment to improve the workforce's skills (Gao \& Yu, 2020; Xiong, 2011). Yet, vocational students, who will play a vital role in upskilling, remain at the bottom of the education hierarchy, suffer considerable societal prejudice (Wang, 2021). This factor needs scrutiny by future researchers to make higher vocational education prominent and insightful.

\section{Most Productive and Influential Institutions}

Table 4 offers a list of institutions with at least four higher vocational education publications. It is interesting to note that China dominated the top institutions that publish higher vocational education research. It is also indicated that Zhejiang Business Technology Institute in China was the leading institutions in this study. Zhejiang Business Technology Institute had published seven 
academic works. Zhejiang Business Technology Institute is one of the leaders' institutions and one of China's five best universities (Zhejiang Institute, 2021). The Wageningen University and Research and the Open University of the Netherlands in the Netherlands and Wenzhou Vocational and Technical College and Suzhou Vocational University in China were in the second rank with six publications. In scrutinising Tables 3 and 4, cross-referencing the relationship between the most outstanding authors and the leading universities. This study depicts that Gong, S. was an energetic researcher associated with Zhejiang Business Technology Institute, China, and Biemans, $\mathrm{H}$. and Gulikers, J. were two vigorous researchers from Wageningen University and Research in the Netherlands.

Table 4. Institutions with at least four publications in publishing higher vocational education

\begin{tabular}{ccc}
\hline Institution & Country & Publications \\
\hline Zhejiang Business Technology Institute & China & 7 \\
Wageningen University \& Research & Netherlands & 6 \\
Open University of the Netherlands & Netherlands & 6 \\
Wenzhou Vocational and Technical College & China & 6 \\
Suzhou Vocational University & China & 6 \\
Zhejiang Institute of Mechanical and Electrical Engineering & China & 5 \\
Hebei University of Engineering & China & 5 \\
Jilin University & China & 4 \\
Shenzhen Polytechnic & China & 4 \\
Vrije Universiteit Amsterdam & Netherlands & 4 \\
Tianjin University & China & 4 \\
National Research University Higher School of Economics & Russia & 4 \\
Shijiazhuang Tiedao University & China & 4 \\
Shanghai University of Medicine \& Health Sciences & China & 4 \\
\hline
\end{tabular}

\section{Analysis by Research Areas}

The review of research articles on a specific area is also essential to recognising the critical disciplines related to higher vocational education (Abdullah \& Abd Aziz, 2020). Table 5 provides 14 study areas with more than ten publications on higher vocational education in the Scopus database. "Social Science" is the most researched area, with 172 publications. This finding was predictable, as the subject under this review is relevant from a social science perspective, which focuses on the relationship between human and social interactions (Asplund \& Kilbrink, 2018). Another field of study that stands out is "Computer Science," with 171 publications. Therefore, both areas are concerned with studying human behaviour besides significantly influencing students' learning processes (Hwang, Wang, \& Lai, 2021; Luo, Zhang, \& Qi, 2017). Another related research area is "Engineering", with 134 publications. Indeed, "Engineering” is one of the many higher vocational 
education areas that has been taught in the syllabus. Employers are satisfied with students' engineering skills and show that fundamental general skill and engineering skills are the essential elements to ensure employers' satisfaction (Salleh, 2019).

Table 5. Research area related to higher vocational education

\begin{tabular}{lc}
\hline \multicolumn{1}{c}{ Subject Area } & Publications \\
\hline Social Sciences & 172 \\
Computer Science & 171 \\
Engineering & 134 \\
Business, Management and Accounting & 34 \\
Mathematics & 32 \\
Physics and Astronomy & 32 \\
Agricultural and Biological Sciences & 22 \\
Decision Sciences & 21 \\
Chemistry & 15 \\
Materials Science & 14 \\
Arts and Humanities & 13 \\
Health Professions & 13 \\
Psychology & 13 \\
Medicine & 12 \\
\hline
\end{tabular}

\section{Network Visualisation Map of Authors' Keywords}

The analysis of the most frequent appearance of keywords in a given set of publications was made possible with the VOSviewer. In this analysis, VOSviewer had mapped the keywords of the authors. Figure 3 provided a network diagram of the keywords in which colour, node sizes, font sizes, and the connecting lines' thickness illustrate the relationship with other keywords (Sweileh et al., 2017). The keyword of "higher vocational education" was discovered to be the most important keyword in this study, with a close nexus to other keywords such as "teaching reform," "school-enterprise cooperation," "teaching mode," "competence," "curriculum," "business website development," and "big data". Thus, it is indicated that higher vocational education has significant developments, including expanding use of technology, the increasing relevance of information and communications systems, and changes in national demography, characterising vocational education and training around the world. In addition, with the rapid development of higher vocational education, the critical goal is to increase overall quality (Ling, Jeong, \& Wang, 2021). For a long time, higher vocational education has used the knowledge-based education paradigm of general higher education. Based on the derived keywords, it is critical to observe the gaps and future research directions on higher vocational education globally. 


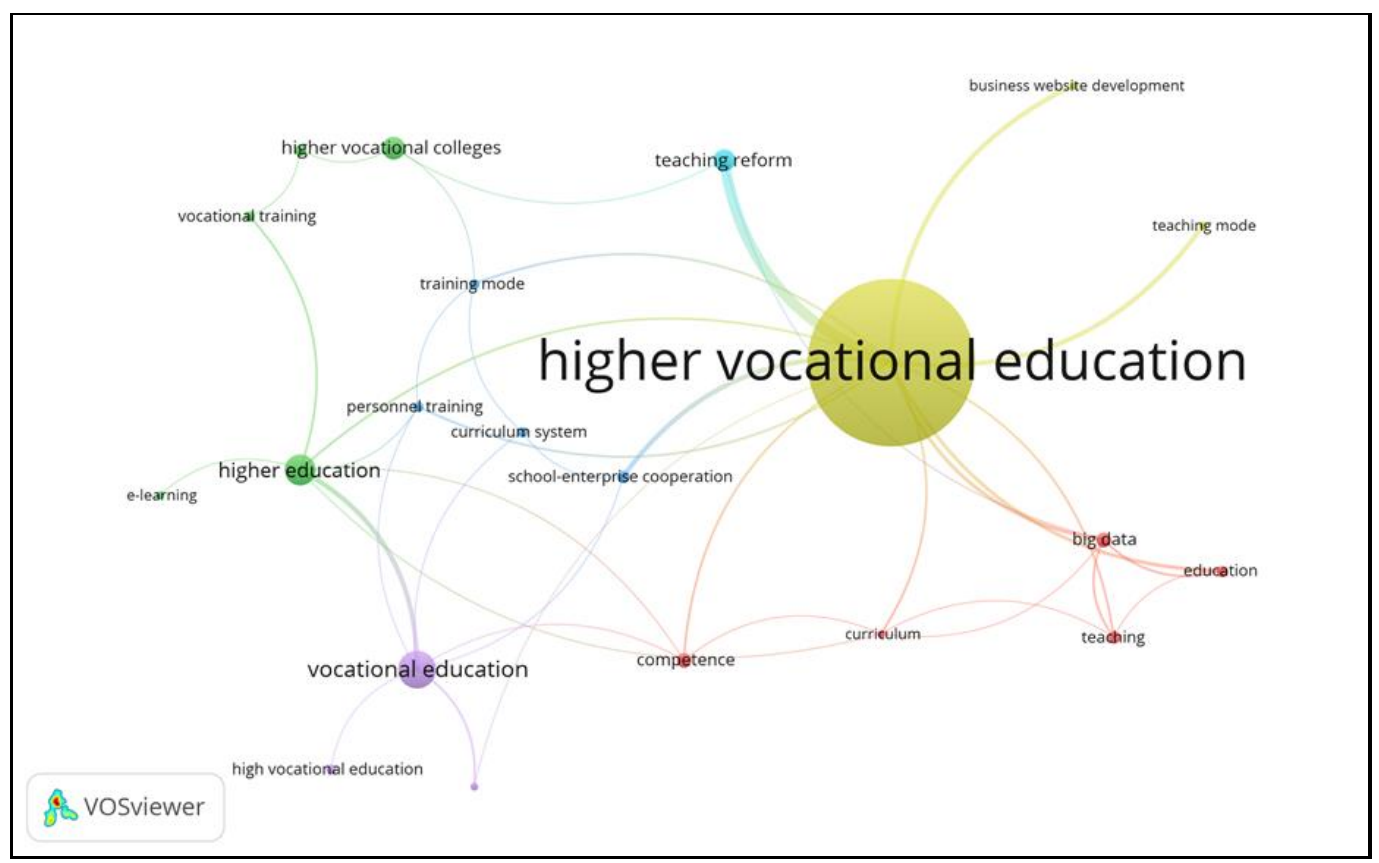

Fig 3: Network visualisation map of authors' keywords in higher vocational education research

\section{Conclusion}

This bibliometric review promotes examining and integrating established directions in higher vocational education research as recent trends continue to emerge. Based on a bibliometric review of 40 years of higher vocational education, the researcher found that the information below provides readers, education practitioners, and researchers with more noticeable realities:

a. The number of publications on higher vocational education had fluctuated, and the highest number of publications was 65 in 2020. It is still minimal, with below than 100 publications annually within 40 years.

b. In terms of countries, China, Russia, and the Netherlands were the top three prominent countries in publishing higher vocational education research. China became the most recognised country for higher vocational education because it focuses on skills and skilled workers to boom its economy.

c. The Journal of Physics Conference Series seems to be the most influential journals in higher vocational education. This is because the Journal of Physics Conference Series has contributed valuable knowledge to allow prospective researchers to source them. The information provided also conveys a message that the Journal of Physics Conference Series, making it easy for readers to identify and exploit relevant details.

d. The Zhejiang Business Technology Institute in China was the leading institution in this study. The Zhejiang Business Technology Institute has seven publications. Zhejiang Business Technology Institute is one of the world's leading institutions and one of China's top five universities. 
e. Gong, S. affiliated with the Zhejiang Business Technology Institute, Ningbo, China, had published five higher vocational education research articles.

f. "Social Science" is the most researched area, with 172 publications. This finding was expected, as the subject under this review is relevant from a social science perspective, which focuses on the relationship between human and social interactions

g. The keyword of "higher vocational education" became the most frequent keywords. Other keywords such as "vocational education", "higher education", "higher vocational colleges", and "teaching reform" were also frequent used by the previous researchers along four decades of higher vocational education research. Thus, it can be confirmed that higher education research takes an interdisciplinary approach, highlighting vocational training, a component of the development of future workers' skills and identity.

\section{Limitation}

Bibliometric studies could indeed project or provide insight into state of the art in a specific field or subject. Despite the valuable information provided by this paper, some limitations should be highlighted to help the readers and future researchers to comprehend better. This study relied solely on documents from the Scopus database as its primary source. Dimensions, Microsoft Academic, and Google Scholar are three additional databases that may be useful for the bibliometric review. Moreover, the prospective researcher will visualise large amounts of data in various situations by using other software programmes such as the R package, BibExcel, CiteSpace, and SciMAT.

\section{Future Research Directions}

This study has been identified the major themes or keywords connected with higher vocational education. Therefore, this bibliometric analysis could generate a proposal for future research based on publication growth trends and author keywords. These aspects are necessary for future researchers to elaborate on the background or address broad concerns with previous higher vocational education research. They may also use another review methodology, such as a narrative review, scoping review, systematic literature review, or meta-analysis, to elaborate on the relationships discovered in this study.

Further studies should also be conducted to determine the trend of higher vocational education publications related to the interventions on specific target groups, academic content or programme syllabus, educational pedagogy, teaching staff, resources, and assessment. Therefore, progressive higher vocational education is frequently a necessary and critical aspect of community 
sustainability to promote and develop vital vocational knowledge and skills. Hence, based upon these bibliometric findings, readers, educators, and researchers would better identify essential information to assess vocational education's value in their future studies.

\section{References}

Abdullah, K. H., \& Abd Aziz, F. S. (2020). Publication trends of safety knowledge research: A bibliometric review. International Journal of Innovation, Creativity and Change, 14(4), 927945.

Aparicio, G., Iturralde, T., \& Maseda, A. (2019). Conceptual structure and perspectives on entrepreneurship education research: A bibliometric review. European Research on Management and Business Economics, 25(3), 105-113. doi: 10.1016/j.iedeen.2019.04.003

Artemenko, D., Artmenko, O., Martynenko, S., \& Cherednychenko, N. (2020). Specific nature of spatial awareness formation of the Bachelor of Technical Higher Education Institution of Ukraine during the basic course. Journal of Technical Education and Training, 12(2), 87-98. doi: $10.30880 /$ jtet.2020.12.01.009

Asplund, S. B., \& Kilbrink, N. (2018). Learning how (and how not) to weld: Vocational learning in technical vocational education. Scandinavian Journal of Educational Research, 62(1), 1-16. doi:10.1080/00313831.2016.1188147

Azer, S. A. (2015). The top-cited articles in medical education: A bibliometric analysis. Academic Medicine, 90(8), 1147-1161. doi: 10.1097/ACM.0000000000000780

Bakhtiyorovna, K. N. (2020). Didactic support of the process of formation of managerial competence of future teachers in vocational education. European Journal of Research and Reflection in Educational Sciences, 8(1), 45-49.

Broadus, R. N. (1987). Toward a definition of "bibliometrics". Scientometrics, 12(5-6), 373-379.

Chukwu, D. U., Anaele, E. A., Omeje, H. O., \& Ohanu, I. B. (2020). Assessing technical vocational education and training (TVET) labour market potentials: Comparison of conferees' opinions. Journal of Technical Education and Training, 12(2), 12-23. doi: 10.30880/jtet.2020.12.02.002

Eduard, A., \& Shashkin, A. (2019). International scientific conference on informatics: Problems, methodologies and technologies. Journal of Physics: Conference Series, 1-5. doi: 10.1088/1742-6596/1202/1/011001

Gao, Z., \& Yu, T. (2020). Research on the development of higher vocational education in China in the $21^{\text {st }}$ Century. Advances in Social Science, Education and Humanities Research, 416, 742-745. doi: 10.2991/assehr.k.200316.162

Handayani, M. N., Ali, M., \& Mukhidin, D. W. (2020). Industry perceptions on the need of green skills in agribusiness vocational graduates. Journal of Technical Education and Training, 12(2), 2433. doi: $10.30880 /$ jtet.2020.12.02.003

Hwang, G. J., Wang, S. Y., \& Lai, C. L. (2021). Effects of a social regulation-based online learning framework on students' learning achievements and behaviors in mathematics. Computers and Education, 160, 1-19. doi: 10.1016/j.compedu.2020.104031

Kamasheva, Y. L., Goloshumova, G. S., Goloshumov, A. Y., Kashina, S. G., Pugacheva, N. B., Bolshakova, Z. M., ... \& Timirov, F. F. (2016). Features of vocational education management in the region. International Review of Management and Marketing, 6(1), 155-159.

Kexin, Y., Wanlong, L., \& Ke, Y. (2016, August). Research on the skill teaching reform of higher vocational education from the perspective of sustainability: Case study of software college. 
Paper presented at 2016 11th International Conference on Computer Science \& Education (ICCSE). doi:10.1109/iccse.2016.7581700

Khalil, G. M., \& Crawford, C. A. G. (2015). A bibliometric analysis of US-based research on the behavioral risk factor surveillance system. American Journal of Preventive Medicine, 48(1), 50-57. doi: 10.1016/j.amepre.2014.08.021

Köpsén, J. (2020). Demands-based and employer-driven curricula: Defining knowledge in higher vocational education and training. Studies in Continuing Education, 42(3), 349-364. doi: 10.1080/0158037X.2019.1661238

Koudahl, P. D. (2010). Vocational education and training: dual education and economic crises. Procedia-Social and Behavioral Sciences, 9, 1900-1905. doi: 10.1016/j.sbspro.2010.12.421

Kuijpers, M., \& Meijers, F. (2012). Learning for now or later? Career competencies among students in higher vocational education in the Netherlands. Studies in Higher Education, 37(4), 449467. doi: $10.1080 / 03075079.2010 .523144$

Ling, Y., Jeong, S. J., \& Wang, L. (2021). Research on the reform of management system of higher vocational education in China based on personality standard. Current Psychology, 1-13.

Llamazares de Prado, J. E., Arias Gago, A. R., \& Melcon Alvarez, M. A. (2021). Theoretical review of the creativity, the key factor in education with visual impairment. Education and Urban Society, 53(1), 68-82. doi: 10.1177/0013124519896863

Luo, N., Zhang, M., \& Qi, D. (2017). Effects of different interactions on students' sense of community in e-learning environment. Computers and Education, 115, 153-160. doi: 10.1016/j.compedu.2017.08.006

McGunagle, D., \& Zizka, L. (2020). Employability skills for 21st-century STEM students: the employers' perspective. Higher education, skills and work-based learning, 10(3), 591-606. doi: 10.1108/HESWBL-10-2019-0148

Melki, H., Bouzid, M. S., \& Mrayeh, M. (2020). University supervisors' expectations for cooperating teachers during a TVET practical traineeship in the field of physical education. Journal of Technical Education and Training, 12(2), 77-86. doi: 10.30880/jtet.2020.12.02.008

Özer, M., \& Suna, H. E. (2019). Future of vocational and technical education in Turkey: Solid steps taken after Education Vision 2023. Eğitim ve Insani Bilimler Dergisi: Teori ve Uygulama, 10(20), 166-192.

Özkaya, A. (2018). Bibliometric analysis of the studies in the field of mathematics education. Educational Research and Reviews, 13(22), 723-734.

Pilz, M., \& Regel, J. (2021). Vocational education and training in India: Prospects and challenges from an outside perspective. Margin: The Journal of Applied Economic Research, 15(1), 101-121. doi: 10.1177/0973801020976606

Salleh, H. (2019). The relationship between engineer skill ability towards manufacturing employer's satisfaction: A fundamental study. Journal of Technical Education and Training, 12(3), 71-76. doi: 10.30880/jtet.2020.12.03.007

Siddiky, M. R., \& Uh, S. B. (2020). Linking TVET with industries in Bangladesh: Need for supportive policies and an approach to TVET. Journal of Technical Education and Training, 12(3), 1-21. doi: $10.30880 /$ jtet.2020.12.03.001

Smirnova, Z. V., Vaganova, O. I., Loshkareva, D. A., Konyaeva, E. A., \& Gladkova, M. N. (2019, March). Practice-oriented approach implementation in vocational education. In IOP Conference Series: Materials Science and Engineering (Vol. 483, No. 1, p. 012003). IOP Publishing. doi: 10.1088/1757-899X/483/1/012003 
Sun, W., Cui, H., \& Xu, C. (2018). Innovative mode of integrated development of higher vocational education based on social interaction theory. Educational Sciences: Theory and Practice, 18(6), 3043-3051. doi: 10.12738/estp.2018.6.204

Sweileh, W. M. (2020). Bibliometric analysis of peer-reviewed literature on food security in the context of climate change from 1980 to 2019. Agriculture and Food Security, 9(1), 1-15. doi: 10.1186/s40066-020-00266-6

Sweileh, W. M., Al-Jabi, S. W., Abu Taha, A. S., Sa'ed, H. Z., Anayah, F. M., \& Sawalha, A. F. (2017). Bibliometric analysis of worldwide scientific literature in mobile-health: 2006-2016. BMC Medical Informatics and Decision Making, 7(1), 1-12. doi: 10.1186/s12911-017-0476-7

Van Eck, N. J., \& Waltman, L. (2010). Software survey: VOSviewer, a computer program for bibliometric mapping. Scientometrics, 84(2), 523-538.

Van Eck, N. J., \& Waltman, L. (2019). VOSviewer manual version 1.6.10. Leiden: Univeristeit Leiden.

Wang, G. (2021). Stepping into the labour market from the VET sector in China: student perceptions and experiences. Studies in Continuing Education, 1-17. doi: 10.1080/0158037X.2021.1872522

Webb, S., Bathmaker, A. M., Gale, T., Hodge, S., Parker, S., \& Rawolle, S. (2017). Higher vocational education and social mobility: educational participation in Australia and England. Journal of Vocational Education and Training, 69(1), 147-167. doi: 10.1080/13636820.2016.1269359

Wild, S., \& Heuling, L. S. (2020). How do the digital competences of students in vocational schools differ from those of students in cooperative higher education institutions in Germany?. Empirical Research in Vocational Education and Training, 12(1), 1-18. doi: 10.1186/s40461020-00091-y

Xian, H., \& Madhavan, K. (2014). Anatomy of scholarly collaboration in engineering education: A big-data bibliometric analysis. Journal of Engineering Education, 103(3), 486-514. doi: 10.1002/jee.20052

Xiong, J. (2011). Understanding higher vocational education in China: Vocationalism vs Confucianism. Frontiers of Education in China, 6(4), 495-520. doi: 10.1007/s11516-0110143-1

Yaakob, M. F. M., Awang, H., Ismail, M. Z., Zain, F. M., Kasim, M., \& Adnan, A. A. Z. (2020). Backward and forward reviews on technical and vocational education and training (TVET) in Malaysia: The evolution and ICT-driven future prospect. Universal Journal of Educational Research, 8(6), 2197-2203. doi: 10.13189/ujer.2020.080601

Zha, Q., Guangfen, Y., \& Shiming, Z. (2017). Higher vocational education reform and development in China. Chinese Education and Society, 5, 425-428. doi: 10.1080/10611932.2017.1408292

Zhejiang Institute (2021). Zhejiang Business Technology Institute | Admission | Tuition | University. $\begin{array}{llll}\text { Retrieved } & \text { February } & 2021, & \text { from }\end{array}$ https://www.unipage.net/en/14273/zhejiang_business_technology_institute 